\title{
Current Situation Analysis of sports Television Broadcasting in China
}

\author{
Kang Tan \\ Chengdu Sports Institute, Chengdu, China \\ Email:373024528@qq.com
}

Keywords: current situation analysis;sports television broadcasting;China

Abstract: This article explores current situation of sports television broadcasting in China and summary the rules of its development so as to promote the benign development of sports television broadcasting in China.

\section{Introduction}

In the 2008 Olympic Games in Beijing, CCTV, holding the sports broadcasting rights in China, completed the task of TV coverage of the games relatively good and completed part of the public signal production tasks of the project, providing public TV signals for more than 200 countries and regions all over the world. There is no doubt that as a national television station, CCTV played a pivotal role in the 2008 Beijing Olympic Games reports, it grasped the opportunity and experienced the whole process of Olympic Games information transmission completely and successfully. It was undoubtedly a historic leap and development for CCTV sports channel which being as a leader of sports television broadcasting industry in China. Based on the broadcasting of this Olympic Games, It can be said that the Chinese sports TV got an unprecedented development opportunity in personnel training, equipment update, dissemination idea renewal, the expansion of the broadcasting platform and many other aspects. Many domestic TV institutions have become the beneficiaries and improved in different degrees. In domestic present limited competition space, in a long stage of future, CCTV sports broadcasting industry in China will remain absolute dominance. Relying on a variety of policy tilt to obtain competitive advantages, CCTV has become the "big MAC"in China's sports broadcasting industry after its primitive accumulation and few domestic peers can compete with. However, Chinese sports television broadcasting industry is by no means a backwater, other sports media and even some of the world famous sports television giants such as NBC, ESPN, SKY SPORTS and so on are looking for a chance to try to break through the stand-off. Therefore, it is not hard to see the contemporary Chinese sports TV broadcasting, being accompanied by the development of sports industry, will change to a certain degree, although the change is likely to be gentle and slow.

\section{Results}

\section{CCTV sports channel-monopoly is hard to shake}

China central television (CCTV) has become the first channel that occupies absolute dominance in China after decades of development. The other local TV stations cannot catch up with it in the capital, talent, equipment, resources, policy tilt and so on.

Additionally,these advantages enable CCTV just like a duck to water in the buy and sell prominent 
feature international sports television market. It is no exaggeration to say that there are no sports events cannot be broadcasted by CCTV, unless it doesn't want to. When each local TV sports channel shutting down or grudging, CCTV sports channel, the leader of the Chinese sports television, have parted ways with these domestic so-called competitors and ambitious to the international first-class sports TV media pursue goal. In fact, before the Beijing Olympic Games, CCTV sports channel was in absolute monopoly in terms of sports television broadcasting in China's TV broadcasting industry, since it occupied policy and"China's first platform" advantages, CCTV used its special position of the national television to realize monopoly for years and then acquired the supreme status of television in China. So long as CCTV remains the national television, its dominance will not be changed. For example, in the Beijing Olympic Games, the Vancouver Winter Olympics and other large-scale comprehensive sports broadcasting, the numerous broadcasting platforms, the long broadcasting hours and the broad shows of CCTV were the most in the Chinese sports TV history, highlighting the strong strength of CCTV.At the same time, the CCTV adopted different forms when broadcasting including live coverage, live studio, news live broadcast, thus it enhanced the communication effect. After the Beijing Olympic Games, CCTV sports channel depended its accumulation of economic strength, talent and brand strength during Beijing Olympic Games, it had become the "big MAC" in Chinese sports broadcasting industry while other domestic peers had fallen far behind.

Additionally, the CCTV further established its monopoly position and announced to its domestic competitors the unshakable dominance.

\section{Local TV sports channel—struggling}

From the end of last century, waves swept channel specialization across China's television industry, there were examples of success and failure at the same time. A case in point was that local TV sports channels were increasingly weak. The fact proved that domestic sports TV media pattern would not change much under the premise of no changes in present market and system. Under the big shadow of the CCTV sports channel, it was almost impossible for the local sports channels to make great achievements. The current domestic local sports channels, in addition to Beijing, Shanghai, Guangdong provincial sports channels which are in benign development, the other sports channels' development foreground is not optimistic. In 2003, almost all of China's domestic provincial stations had its own sports channels, while close to the end of 2007 , the number of these channels decreased to 17 . What's more, not all of these 17 sports channels broadcast sports programs. From the perspective of the call,these local channels had so many names such as "physical health channel", "sports leisure channel", "sports entertainment channel", "sports tourism channel" and so on. A number of provincial sports channel director even admitted that rating of sports channel and advertising revenue were at the bottom of the list chronically,facing the possibility of being phased out directly and being likely to be shut down at any time in each channel of their own respective units.

Under the strong extrusion of CCTV sports channel, each local TV sports channels, instead of just sitting around, they have taken different approaches, trying to obtain market share from Chinese limited sports TV broadcasting market. For these local channels, it is impossible to meet as equals with CCTV, but for the sake of their own survival, adopting a loose joint should be the safest and most effective form under the present condition. And only in this way can these local channels grasp at straws temporarily especially after losing ESPN, which is the most stable program resources for Chinese local channels. As early as 2004 during the Olympic Games, the domestic provincial sports channels have joint tournament in Athens for sports events reports. In 
2007, seven local television sports channels came together and formed the so-called "China's biggest sports TV broadcast platform" - CSPN, trying to further improve the possession of resources and markets through integration and extension of broadcast platforms. Hubei, Shandong, Liaoning, Xinjiang, Inner Mongolia, Jiangxi, Jiangsu and other seven TV sports channels participated. The appearance out of the blue of CSPN is likely to have some effects on the pattern changes of domestic sports TV media, but will not be enough to have a deep impact on CCTV sports channel. Because from the overseas sports broadcast rights purchase and program production team perspective, there is a huge gap between CCTV sports channel and the provincial sports channels although they joint together. For example, from a single perspective of the scale of production team, CCTV sports center has more than 1000 people, while the vast majority of provincial sports channel production teams are only equivalent to $1 / 20 \mathrm{of}$ it, apart from that, there is also a big gap between the personnel quality, technology and equipment. However, on the perspective of most important program resources of sports channel, CCTV is alone big. Due to the special economic strength and policy, CCTV can not only buy the exclusive broadcasting right of Olympic Games and World Cup that are at the core of the world's most high-profile in mainland China, and in the present condition, the CCTV also has $90 \%$ of the domestic and $80 \%$ of the international competition resources. Therefore, faced of CCTV, a strong opponent, it will be very difficult for CSPN, if it wants to get a certain sports television market share in the sports TV broadcasting market in China, what's worse, the loose joint foundation is not solid, the coordination problem exists in local and overall interests is its inherent dysentery. The prospect of CSPN is not as optimistic as its members suppose.

For a sports TV channel, whose most important supporting program is broadcasting sports events, while each local TV sports channel is seen as vulnerable on program resource. The access of acquiring program resources depends on strong economic strength. It is possible to purchase sport events broadcasting right only with the financial security, and only in the economic developed areas, the wonderful sports broadcasting can get consistent quality of advertising revenue. Television can form a virtuous cycle and develop with appropriate advertising revenue. It precisely illustrate this point that Beijing, Shanghai, Guangdong, these three economy-strong provincial sports channel have succeed. At present, Beijing, Shanghai and Guangdong provincial sports channel are still well ahead of the domestic counterparts, and keep a relatively advantage of CCTV sports channel in the local audience market, and this kind of situation will also remain. The particularity of sports TV channel, therefore, are highly dependent on the program resources, funds, purchase of sports broadcasting rights in China, most of provinces and cities in the developing world, their economic strength obviously cannot meet the requirements, the vast majority of domestic provincial television cannot afford sports copyright fees, thus they lost in major domestic and international sports events broadcasting rights. Having no sports broadcasting rights will inevitably shut down these provincial television stations.

\section{Pay TV sports channel-it will take time}

Although pay-TV is commonplace in Europe and the United States television viewers, but is a new thing in China. Chinese people are still used to license per 10 yuan a month for each family, it really equals to watch TV free, especially for the sports TV stations that need large sums of money to buy sports TV broadcasting rights. Therefore, from 2007-2008 season, when Tiansheng media bought the next three years broadcasting rights in mainland China of the Premier League, part of the angry fans claimed to resist European football channel of Tiansheng media, thus letting Tiansheng media wiped out in three years and met free time of Premier League back three years later. Thus, in a long period of time, the marketing of Tiansheng media was very difficult, recently 
Tiansheng media has experienced national layoffs one after another. It goes to show that the operating condition of Tiansheng is not very ideal.

Tiansheng media's original intention is to reach to the expansion of broadcasting space and transformation of the dissemination through the possession of sports resources and integration. It has ever caused great repercussions in the sports TV broadcasting market in China, and even determined the survival of the conditions of ESPN and some provincial sports channels. Of course, it is the landmark case that overseas capital have a significant impact on the future development of Chinese sports TV. It has positive epoch-making significance. However, it seems that it is not yet ripe, what Tiansheng media have done has not bring any good results, this deserves our discussion.

First of all, Chinese people are not get into the habit of paying to watch TV. Under China's current economic condition, under the current level of national income, it is inappropriate to force out pay-TV and it is bound to be resisted by the vast majority of the audience. It is the place of Tiansheng media's lost that it lacks of careful and practical market survey and forecasts the marketing situation of overly confident. Speaking of premium sports TV program, Tiansheng media is not the pioneer of China. CCTV launched China DTV - soccer and China DTV - golf/tennis channel as early as a few years ago, while CCTV has such numerous sports events resources that it can balance the two premium and open sports channel CCTV5 as many as three channels broadcasting needs and wonderfulness, thus the three channels all work well at present. However, Tiansheng media, which has limited sports resources, exposes his own weakness by launching subscription program forcely.

Secondly, the proportion of sports fans in Chinese audience is lower. Through carefully analyzing China's television audience we will find that, because of the influence of cultural traditions, national character, income level, employment pressure and many other factors and constraints, there are not so many Chinese audience who would like to watch sports events broadcast, what's more, the audience who like football is more limited in very limited TV audience of sports. Additionally, CCTV sports channel live broadcast four of Europe five major league matches through free open circuit TV, only lack of the Premier League. Hence, the Premier League is not a must-see for Chinese fans, it is no more than the icing on the cake of sporting events. Tiansheng media is obviously over optimistic and overestimated Chinese fans' love to the Premier League before then.

Finally, China's TV network operation mode is unable to break through the shackles of pay TV sports. At present, the situation of Chinese television network cannot be changed either by administrative means or by means of market. The profit pattern of pay to watch sports games still cannot meet the expectations of investors. So far no one is able to give an objective answer to the question of long does it take to this market cultivation period. Although the exploration made by Tiansheng media on paid sports TV in the market of China is extremely valuable, but the first purpose for capital entering the market is to reap the benefits, the capital will turn to other capital market to seek profits if it can't get benefits from sports TV audience. As a result, Tiansheng media will face great challenges. Pay TV sports maybe an important mode of broadcasting and operation in China's sports TV in the future, but there need to have a long warm-up period before that, whether successful or not, the Tiansheng media plays his own role and has made the beneficial exploration. 


\section{Conclusions}

Therefore, the Chinese sports TV got great development during the Beijing Olympic Games, traditional sports TV channel is still dominant in the sports media market. According to the law of sports TV transmission, in the next few years, the monopoly position of CCTV sports channel remains unshaken under the condition that CCTV broadcast privilege policy unchanged, local TV sports channel is full of crisis, and the development of pay sports TV will be difficult, the pattern of the Chinese sports television market will have few changes, while the communication value of the technology innovation will bring a better future for the network TV, mobile TV and other new media.

\section{References}

[1] Zhiming Cheng. The precious cultural heritage_- the Beijing Olympic Games and Paralympics public TV signal tittle-tattle[J]. Modern TV technology, 2009 (40: 56.

[2] Jiang Heping, Respect and protect the Olympic TV rights, Journal of Radio and Television, Vol.5, May.2008, pp.68.

[3]Liu Xingang, on the maintenance and use of the Olympic intellectual property, Sport and Science, Vol.3, Mar.2002pp.81.

[4]Li Hui, Chinese sports TV Survival, Academia Press, 2007, pp.46.

[5]Zhang Yahui, Modern Olympic TV rights management and marketing, Sports Science Institute of Shanxi Normal University, Vol. 10, Dec.2007, pp.47. 